\title{
Corruption Factor as a Destabilizing Element of Development of the Space Industry
}

\author{
Andrii Prykhodko \\ Ph.D. in Law, Doctoral Student, Scientific Institute of Public Law \\ (Kyiv, Ukraine) \\ E-mail: prikhodko.a.a@ukr.net \\ https://orcid.org/0000-0002-2782-3256 \\ Vitaliy Oksin \\ Ph.D. in Law, Doctoral Student, Scientific Institute of Public Law \\ (Kyiv, Ukraine) \\ E-mail: 6222410@ukr.net \\ https://orcid.org/0000-0001-6080-7752
}

\begin{abstract}
Prykhodko, Andrii, and Vitaliy Oksin (2020) Corruption Factor as a Destabilizing Element of Development of the Space Industry. Advanced Space Law, Volume 5, 71-82. https://doi. org/10.29202/asl/2020/5/7
\end{abstract}

This work is devoted to the analysis of the phenomenon of corruption, its impact on the development of the space industry, because under the condition of the rapid development of new space technologies, building a new model of the space economy and generally rethinking the prospects of the space industry by the world, the exploration of its unknown spaces - this question is extremely relevant. In a global sense, corruption as a transnational socio-legal phenomenon is, firstly, a type of behavior of persons with a special status (particularly in the sphere of making individual decisions that have legal consequences), in which the interests of such a person occupy a privileged position over public or state ones; secondly, it is a reviled ideology of society that allows, contrary to the law, to commit, allow or encourage unethical and illegal behavior of authorized persons. In a general sense, it is a comprehensive phenomenon that includes manifestations of any abuse of a special status on the one hand, and on the other - inducement and active actions before their implementation by other interested persons. In other words, it is a two-way relationship, a symbiosis of needs and benefits. It is proved that corruption in the space industry is manifested by the aggregate indicator of its existence in the state, in its main sectors. The space industry is hindered in its development precisely because funds that should potentially be used for research and development of outer space are not being used for their intended purpose. Accordingly, there is no innovation activity, and technological progress is minimal. Therefore, the priority is to eliminate corruption both in the world and in individual countries, because it, like a viral infection, tends to migrate, threatening the entire humanity.

(C) Prykhodko, Andrii, 2020

(C) Oksin, Vitaliy, 2020 
Keywords: eradication of corruption, destabilization, corruption, space sphere, outer space, world cooperation.

Received: March 21, 2020; accepted: April 27, 2020

\section{Introduction}

There is no need to prove the thesis that corruption is a negative phenomenon that massively permeates all spheres of both public and state sectors, not just in two, but in a significant number of states around the world.

The modern existence of the analyzed phenomenon is historically conditioned and quite natural. For millennia, corrupt practices have been either encouraged or prohibited. It is clear that this was done in various ways, by various authorized entities and using the tools that met the needs of the time. However, it should be understood that corruption is, first of all, a conscious choice of everyone, regardless of the active or passive nature.

The international community has long defined corruption as a mass phenomenon, a global disease that gradually poisons key areas of national and global economic development. The space industry is no exception, because space has always been a source of inspiration for researchers and scientists, who, by the way, have significantly expanded the scientific knowledge of mankind about it, which in the future has greatly improved our daily lives (The future, 2019).

Commercial interest in space technologies of private business entities encourages them to search for forms of cooperation with state institutions that have a powerful administrative resource and technological heritage of the era of "military space races." At the same time, the state is also interested in attracting material, financial, intellectual, and other types of private investment for the quality upgrade of its production and service capacities (Malysheva \& Hurova, 2019: 73). This situation is now the starting point for the exploration and use of outer space within the framework of a public-private partnership, the ways of deployment of which significantly depend on national policies, legal regulators, and the economic background created by the state. But public-private collaboration in the field of space activities has positive aspects as well as negative ones. In this case, we are talking about the existence of manifestations of corruption in the state sector in general, and in the space industry in particular.

So, in the conditions of the rapid development of new space technologies, building a new model of the space economy and generally rethinking by the world the prospects for the space industry, the development of its unknown spaces, it is extremely important to investigate whether corruption affects the development of the space industry.

\section{Definition of the term "corruption" in international legal acts}

For a careful consideration of the issue raised, we consider it necessary to investigate how the term "corruption" is defined in international legal acts, since knowledge of the essential characteristics of the subject gives an almost exhaustive idea of its essence. The technical perfection of the adopted actions depends on how well the rule-makers apply the means of legislative technique and especially definitions in their activities (Tkalya \& Pravova, 2011: 65 ), and, as a result, how the visible phenomenon realizes itself in reality, its essence is demonstrated. There is a separation from other objects (Khvorostyankina, 2020). 
In the Model Law "On the basis of legislation on anti-corruption policy" of 15.11.2003, corruption is bribery (receiving or giving a bribe), any illegal use by a person of their public status, involving the receipt of benefits (property, services or benefits and/or advantages, including non-property) for themselves and their relatives contrary to the legitimate interests of society and the state, or illegal provision of such benefits to a specified person (Model law, 2003).

It should be clarified that persons with public status are persons who permanently, temporarily or by exclusive authority perform staff or official duties in state and local government bodies, state and municipal institutions, as well as persons who perform managerial functions in state and municipal enterprises or in non-profit (including foreign and international) organizations that are not state bodies, local government bodies or their institutions (Model law, 2003).

In "Practical measures to combat corruption," this phenomenon is defined as "violation of ethical (moral), disciplinary, administrative, criminal nature, manifested in the illegal use of their official position by the subject of corruption" (Practical, 1991). We should add that the Reference document on the international fight against corruption interprets the concept of corruption as "abuse of state power for personal gain" (Zadorozhniy, 2016: 50).

In turn, the Civil Convention against corruption contains a specific purpose definition of this term, which means direct or indirect extortion, offering, giving or receiving a bribe or any other improper benefit or opportunity to obtain it, which violate the proper performance of any obligation by the person who receives the bribe, improper benefit or opportunity to have such a benefit, or the conduct of such person (Civil Convention, 2003).

So, in a global sense, corruption as a transnational socio-legal phenomenon is, firstly, a type of behavior of persons with a special status (in particular, in the sphere of making certain decisions that have legal consequences), in which the interests of such a person occupy a privileged position over public or state ones; secondly, it is a reviled ideology of society that allows, contrary to the norms of the law, to commit, allow or encourage unethical and illegal behavior of authorized persons.

In a general sense, it is a widespread phenomenon that includes manifestations of any abuse of special status on the one hand, and on the other - inducement and active actions before their implementation by other interested persons. In other words, it is a two-way relationship, a symbiosis of needs and benefits. The highest corruption manifestation is bribery, which in any case, should be criminally punishable with abuse of influence, laundering of proceeds from crimes related to corruption and financial fraud.

It is worth noting that the variety of definitions of corruption indicates the complexity and versatility of this phenomenon, so the descriptions of this concept, are in constant development (Trepak, 2015: 196).

\section{International retrospective of the development of standards to combat corruption}

As it has already become clear from the previous provisions, there are now a number of fundamental international acts — specialized and side ones — related to certain aspects of international legal regulation of the fight against corruption in the world. The initiators of their adoption (union recognition of the problem and the same, cooperative opposition to it by a group of states of the world) are the UN bodies, the EU, the CIS - that is, global and regional international organizations, as well as international organizations created under their auspices. 
We will try to analyze the international anti-corruption standards in a retrospective aspect.

Let's start with the fact that in the international arena, active disapproval of all kinds of corruption, including bribery, began in the second half of the twentieth century. One of the first documents in this area is UN General Assembly Resolution 3514 (XXX), adopted on December 15, 1975, "Measures against corruption practiced by transnational and other corporations, their intermediaries and other parties involved" (Measures, 1975). This document calls on all governments to take all necessary measures at the national level to prevent and combat corruption, as they deem appropriate, including legislation (Klimova \& Kovalova, 2015: 20-21). This need was due to the transition to a new international economic order, where the activities of transnational corporations were closely monitored (Measures, 1975).

This document proposed the introduction of a national system for monitoring the activities of corporations, as well as the collection, processing, and interstate exchange of information on the state of corruption in countries. The UN Center for transnational corporations was defined as the analytical center for such information (Measures, 1975).

On 24 May 1989, the United Nations Economic and Social Council proposed the eighth United Nations Congress on the prevention of crime and the treatment of offenders and its preparatory meetings to explore ways and means to promote compliance with the Guidelines for the effective implementation of the Code of conduct for law enforcement officials. It was proposed to apply the provisions of this act to all law enforcement officials, regardless of their departmental affiliation, with the mandatory development of specialized national codes (A/ CONF.144/28/Rev.1, 1990), which initiated norms of required behavior of such persons.

Moreover, the international code of conduct for public officials as an international UN document was adopted on July 23, 1996, and declared a fundamental rule - a public position is a position of trust, which provides for the obligation to act in the interests of the state. Such persons must be attentive, fair, and impartial in the performance of their functions and, in particular, in their relations with the public. They will never give any undue preference to any group of persons or individuals, discriminate against any group of persons or individuals, or otherwise abuse the powers and authority granted to them (International Code, 1996).

In 1990, the Eighth UN Congress in the resolution "Corruption in public administration" (Resolution A/CONF. 144/28/Rev.1, 1990) noted that the problems of corruption in public administration are universal and their harmful impact is felt throughout the world. The international community is agitated by transnational corruption and proposes to add criminal liability for bribery abroad to national legislation (Vanovskaya, 2018: 9).

At the same time, "Practical measures to combat corruption" have been adopted. The document identified the most important tasks for overcoming corruption. Accordingly, governments should: review the adequacy of their criminal legislation, including procedural rules, in order to respond to all types of corruption; develop administrative and regulatory mechanisms to prevent corruption; establish procedures for identifying, investigating and convicting corrupt officials; and develop legal provisions for the confiscation of funds and property acquired as a result of corruption; take appropriate measures against enterprises involved in corruption (A/CONF.144/28/Rev.1, 1990). Separately, the Committee of Ministers of the Council of Europe adopted the Programme of action against corruption in November 1996, and the United Nations Declaration on combating corruption and bribery in international commercial transactions was solemnly proclaimed by the General Assembly on 16 December of the same year. 
This international document, in order to promote economic and social development, protect the environment, promote social responsibility of private and public corporations, and combat and prevent corruption and bribery in all countries (A/RES/51/191, 1997), contains the necessary conditions for achieving them. There are 12 such conditions, in particular, for example, the necessary ones are considered:

1) ensure the effective application of existing laws and promote the adoption of laws for this purpose where they do not exist;

2) recognize the giving of bribes to foreign public officials as a criminal offense, the objective side of which is such actions as:

a) the offer, promise or transfer of any payment, gift or another benefit, directly or indirectly, by any private or public corporation, including a transnational corporation, by an individual of a state, to any public official or elected representative of another country, as improper remuneration for the performance or refraining from performing the duties of that official or representative in connection with an international commercial transaction;

b) requiring, accepting or receiving, directly or indirectly, by any official or elected representative of a state, payments, gifts or other benefits in any private or public corporation, including a transnational corporation, or an individual from another country, as improper remuneration for the performance or refraining from performing the duties of that official or representative in connection with an international commercial transaction;

3) develop or apply standards and accounting methods to prevent and combat corruption, bribery and related illegal activities (A/RES/51/191, 1997), and others.

Within the framework of this act, an attempt was made to distinguish such terms as "corruption," "bribery," "unlawful gain," "illegal enrichment." However, the American Convention against corruption, adopted at the third plenary session on March 29, 1996, differs as a more precise one from the previous document (B-58, 1996). A United Nations framework Convention against organized crime of 21.07.1997 actually indicates that corruption is one of the three main means (the other two are violence and intimidation) that enable the leaders of organized crime to profit, control territories, foreign and domestic markets, continue their criminal activities and penetrate the legal economy (Zadorozhniy, 2016: 50).

Later, in November 1997 and May 1998, resolutions were adopted that led to the conclusion of a partial and expanded agreement on the establishment of the "Group of States against Corruption (GRECO)," which aims to expand the capabilities of its members in the fight against corruption by monitoring their compliance with their obligations in this area (Resolution (98) 7, 1998).

On May 5, 1998, the Charter of the group of states against corruption (GRECO) was adopted, the purpose of its activities is to improve the competence of its members in the fight against corruption in order to take action through a dynamic process of joint assessment of methods of conduct and equal influence in accordance with their obligations in this field. To achieve this, the Group monitors compliance with the anti-corruption Guidelines adopted by the Committee of Ministers of the Council of Europe on 6 November 1997 and the implementation of international legal instruments adopted in accordance with the Anticorruption action program (Resolution (98) 7, 1998). 
Noting the twenty principles of the fight against corruption, it should be clarified that the Committee of Ministers of the Council of Europe at its $101^{\text {st }}$ session noted that the fight against corruption should be multidisciplinary and cooperative.

The relevant Resolution No. R (97) 24 defines 20 basic principles on how such activities should be implemented at the national level, in particular:

a) take effective measures to prevent corruption and, in this regard, raise public awareness and promote ethical behavior;

b) ensure that national and international corruption is criminally punishable act;

c) ensure that those responsible for preventing, investigating, prosecuting and adjudicating corruption cases are independent and autonomous;

d) provide appropriate measures for the confiscation and deprivation of income as a result of cases of corruption;

e) provide appropriate measures to prevent pressure on lawyers who are engaged in exposing corruption (Resolution (97) 24, 1997), and others.

GRECO monitors all its member states on an equal basis through mutual assessment processes and pressure from other member states. All states, without exception, participate in the evaluation and enforcement procedure. The monitoring process of the Group consists of: 1) a horizontal assessment (all states are evaluated during assessment rounds), which ends with recommendations on necessary legislative, institutional and practical reforms; 2) an implementation procedure, the purpose of which is to provide an assessment of the measures that states are taking to implement the recommendations (Zadorozhniy, 2016: 53).

Let us also consider the Criminal Convention against corruption (Criminal Convention, 1999) and the Civil Convention against corruption (Civil Convention, 2003), which were adopted by the Council of Europe in 1999.

Since the Programme of action against corruption encourages the coordinated recognition of corruption-related crimes as criminal, the strengthening of cooperation in the prosecution of persons suspected of committing such crimes, as well as the creation of an effective mechanism for further action on an equal basis, it has become necessary to conclude a criminal Convention as soon as possible (Criminal Convention, 1999).

Chapter II provides for measures to be taken at the national level, in particular, the establishment of criminal liability for: 1) the giving of bribes to national public officials or their receiving by individuals or by a member of a national representative body exercising legislative or executive powers; 2) bribery by an official of any other state or by a member of an elected body that performs legislative or executive functions in any other state; 3) giving a bribe in the private sector, that is, to a person who holds senior positions in private enterprises or works for them in any capacity, and vice versa - responsibility for its receipt by these persons; 4) abuse of influence, laundering of proceeds derived from crimes related to corruption, issuing an invoice or use of an account or any other accounting document or record containing false or incomplete information, illegal failure to make a payment record (Criminal Convention, 1999), and the like.

At the same time, cooperation, immunity, jurisdiction, and the need to impose liability of legal entities for these crimes are separately determined. The Group of States against corruption monitors the implementation of this Convention by the Parties (Criminal Convention, 1999).

Noting the Civil Convention on combating corruption, it should be clarified that the need for its adoption was due to the fact that civil legal means of obtaining compensation for damage caused as a result of corrupt actions were not directly enshrined in international documents. 
The document contains several recommendations that are necessary for national adoption in order to protect individuals who are harmed as a result of corrupt practices. As in the previous document, the implementation of this Convention by the Parties is monitored by the Group of States against corruption (Civil Convention, 2003).

In view of all the above, many scientists consider the United Nations Convention against corruption of October 31, 2003, to be the first global document in the field under study, which is aimed at promoting and strengthening measures to prevent and combat corruption more effectively and efficiently (United Nations, 2003), since it laid the foundations of a universal system for fighting corruption. This Convention is considered to have a significant international impact, as it is supported by both international organizations and specialized agencies of the UN system, such as the World Bank, the International Monetary Fund, and the governments of most countries of the world (UNODC).

The Convention is based on two key principles: measures to prevent and combat corruption (Zinchuk, 2018). The Convention under review establishes obligations to criminalize certain acts, take preventive measures in the public and private sectors, establish international cooperation in investigation and law enforcement, take technical support measures, and also contains a provision on asset recovery (Petrashko, 2011: 90-91). Today, this document is a so-called basis for bringing the national legislation of each state party in line with generally recognized methods and measures to prevent and combat corruption (Zinchuk, 2018).

At the same time, in the EU, an important step in the fight against corruption was the publication by the European Commission of the Communique of 28.05.2003 on the comprehensive anti-corruption policy of the European Union. It defined the main principles of the fight against corruption in the EU, described the principles for improving anti-corruption in new member countries, candidate countries and third countries. In addition, the Council of the European Union issued a Framework decision "On combating corruption in the private sector" No. 568 of 22.07.2003, which defined the concept of "active" and "passive" corruption, and established sanctions for such crimes (Zinchuk, 2018).

Another platform for cooperation in preventing and combating corruption is the Organization for economic and social development (OECD) and, in particular, its Anti-corruption Network for Eastern Europe and Central Asia. As part of the work of the OECD in 2003, representatives of the governmental delegations of Armenia, Azerbaijan, Georgia, the Russian Federation, Tajikistan, and Ukraine approved the Istanbul action plan for fighting corruption of the OECD Anti-corruption Network for Eastern Europe and Central Asia. The main principles of the Istanbul action plan are the development of an effective and transparent public service system, strengthening the fight against bribery and ensuring integrity in business, and supporting active public participation in reforms (Klimova \& Kovalova, 2015: 23).

These acts are only part of the overall array of international legal framework in the field of combating and preventing corruption. In addition to these, the Council of Europe Convention on laundering, search, seizure, and confiscation of the proceeds from crime and on the financing of terrorism of 16.05.2005 and the UN Economic and Social Council Resolution entitled the Bangalore principles of judicial conduct of 27 July 2006 No. 2006/23, Recommendation CM/ Rec (2010) 12 of the Committee of Ministers of the Council of Europe to Member States on judges: independence, effectiveness, and responsibilities, adopted by the Committee of Ministers of the Council of Europe on 17 November 2010, Resolution No. 1943 (2013) of Parliamentary Assembly of the Council of Europe "Corruption as a threat to the rule of law," and many others are also of significant importance. 
So, in the international arena, active condemnation of all types of corruption, including bribery, began in the second half of the twentieth century. At the beginning of the emergence of international legal mechanisms to combat corruption, its existence was recognized exclusively in the field of transnational business. Over time, the world begins to discuss corruption in public administration.

\section{Influence of corruption on the development of the space industry in Ukraine}

As soon as people moved from abstract thinking to the practical use of outer space for peaceful purposes, space law was born. This happened on October 4, 1957, when the first satellite flew around the planet Earth at an altitude of more than 200 kilometers above the state borders of sovereign States. None of them protested to the state that owned the first satellite, which led to the emergence of the first rule of space law "instant principle" - that any country has the right to launch artificial civil satellites into earth orbit without asking permission from other states (Kobzar \& Danylenko, 2019). Since then, a rapid development of the space industry began, which was initially under the monopoly of governments - the only entities that could afford complex and risky projects (Christensen \& Magnus, 2019) that were associated with the exploration and development of outer space. Today\&apos;s review of the space ecosystem shows the dynamics of changes - space activities are no longer the exclusive prerogative of state institutions. More and more new companies, from small businesses with two people to large corporations, are creating a variety of different business concepts in the field of space activities. Besides, companies that have been engaged in space activities for decades are rethinking and adjusting their approaches in the context of ongoing changes (Christensen \& Magnus, 2019).

Today the rocket and space industry of Ukraine has two priority state tasks: create and implement space and space-rocket projects by the National target scientific and technical space program of Ukraine, focused on solving national economic tasks and getting greater economic returns from the use of space products (satellite information from national satellites for Earth observation, satellite communications, telecommunications, broadcasting, navigation services, research, and experiments); creation of modern missile weapons for the needs of the Armed Forces of Ukraine with a focus on ensuring the return on public investment due to possible subsequent exports.

Taking into account the chronic shortage of budget funds and the forecast data on the state's economic development for the near and far future, it is quite problematic to solve these problems using the traditional approach. Taking into account that the country now owns the majority of enterprises in the space industry, and private companies have just begun to participate in commercial space activities, a possible way out of this situation is to expand public-private partnerships.

According to article 1 of the Law of Ukraine "On the public-private partnership," state partners can be the state of Ukraine, the Autonomous Republic of Crimea, territorial communities represented by the relevant state and local government bodies (Pro derzhavnopryvatne partnerstvo, 2010). In the field of space activities, the state acts as a partner in the state space Agency of Ukraine.

That is why, in our opinion, corruption in the space industry should be considered in a broad sense. Corruption of officials who are public persons directly related to the development 
of the space industry is only one side of the phenomenon under study. Also, the issues of combating corruption in the sphere of forming budget funds, providing administrative services, education, aerospace and defense industries, the interaction between the state and business, and so on are of great importance. Accordingly, corruption in the space industry is manifested by the aggregate indicator of its existence in the state, in its main sectors.

Taking into account the urgent need to adapt the space industry to the market economy as soon as possible, taking into account all the above, it is necessary to amend the Law of Ukraine "On public-private partnership" and provide the following:

a) give the state policy status to relations between the state and its private partners in the space industry;

b) formulate a clear transparent mechanism for interaction of organizations and enterprises in the industry with private partners (to minimize corruption risks), providing maximum motivation for their involvement in practical activities (publicprivate partnership in the space sector should become attractive for business);

c) provide for the right to create legal structures in the space industry of Ukraine with the participation of public and private partners, the share of state ownership of which can be used for the implementation of business ideas that will contribute to the expansion of international activities of Ukraine in this field;

d) when creating public-private partnership structures, provide safeguards for private partners for their mandatory preservation in the staff of space technology production facilities and their support, despite changes in management, the need to consolidate assets and then divide them into segments based on new business strategies with a shift in emphasis towards creating more profitable products, and so on.

According to Bank of America Merrill Lynch, the main driving force of the new space race will remain the interests of the defense sector. Still, the Space age 2.0 will also be characterized by other factors: innovations of private companies, commercial activities, attracting new countries, reducing the cost of space launches (2017). This, in turn, will encourage all subjects of space activities to search for optimal forms of cooperation (public-private cooperation, international cooperation, etc.). Therefore, minimizing corruption factors is a priority for the Ukrainian political elite. Although Ukraine is not among the ten least corrupt countries for the results of the Corruption Perceptions Index (Corruption Perceptions Index, CPI) ${ }^{1}$, it is hoped that the space industry will become an example for other spheres in preventing corruption and will lead the state to the highest level of this rating. After all, in countries where the society is free from corruption, there is a transparent, responsible and conscious decision-making on the formation of anti-corruption policy and, accordingly, its virtuous implementation. Citizens, first of all, respect themselves and others - a violation of their rights is considered unacceptable. Any discriminatory manifestations are mostly absent, since it is not appropriate to speak about the absolute in this case, but it is quite possible to assert about the ideal. Society really can influence the government by exercising its constitutional right to participate in making various

\footnotetext{
${ }^{1}$ For example, Denmark is considered one of the least corrupt countries in the world. This is confirmed by the annual analytical results Of the corruption Perceptions Index (CPI), an indicator that has been calculated by Transparency International since 1995 (the organization itself does not conduct its own surveys, but calculates the Index based on 13 studies by reputable international organizations and research centers) (Corruption Perceptions, 2019). So, in recent years, Denmark is the undisputed leader in the world, which with slight fluctuations, but retains its position in the top ranking of the least corrupt States.
} 
political and economic decisions. Citizens and authorities are subject to the rule of law. Still, they have the right to free expression of their opinions, honest and open media, and they are own moral and ethical right to resist corrupt officials and business people.

\section{Conclusions}

All countries are different in all aspects. There are no identical ones. In some countries, the rule of law prevails, the state apparatus functions smoothly, the economy develops steadily, citizens are protected socially, and young people develop their talents and skills. And in others, chaos reigns - citizens complain about the state power, pensioners and young people are vulnerable almost unprotected layer of the population, and the ruling elite has all the possibilities beyond understanding - unprecedented income: offshore accounts, their air and sea vessels, foreign villas or even castles.

It is clear that in such conditions, the space industry of a particular country is somewhere better but somewhere less developed. However, to sum up, we should answer the main question raised in this study: does corruption affect the development of the space industry? So, of course, it changes. If this phenomenon were harmless and did not cause global consequences, would the international community take the issue of its eradication so seriously? The answer is obvious.

Global cooperation in the fight against corruption is the primary mechanism for reducing its manifestations. Sharing experience, conducting joint discussions, including seminars and symposiums, as well as providing material, information, or other resources to countries that are "outsiders" in the process of eliminating corruption on their territory - this is the key to the world's security from its mass spread. These are instruments of its containment, which in modern conditions, are supplemented by a variety of innovative ones, which, by the way, confirm their effectiveness.

The space industry is hindered in its development precisely because funds that should potentially be used for research and development of outer space are not being used for their intended purpose. Accordingly, there is no innovation activity, and technological progress is minimal.

Therefore, the priority is to eliminate corruption both in the world and in individual countries, because it, like a viral infection, tends to migrate, threatening all of humanity.

\section{References}

A/CONF.144/28/Rev.1 (1990) Corruption in public administration: Resolution VIII UN Congress on Crime Prevention and Offender Management (Havana, August $27-$ September 7). https://www.unodc.org/documents/congress/Previous_Congresses/8th_ Congress_1990/028_ACONF.144.28.Rev.1_Report_Eighth_United_Nations_ Congress_on_the_Prevention_of_Crime_and_the_Treatment_of_Offenders.pdf

A/RES/51/191 (1997) Declaration on Combating Corruption and Bribery in International Commercial Transactions of December 16, 1996.

B-58 (1996) American Convention against Corruption, adopted at the third plenary session on 29 March 1996. http://www.oas.org/en/sla/dil/inter_american_treaties_B-58_against_ Corruption.asp

Christensen, Carissa, and Sandra Magnus (2019) The Space Industry Is Getting Down to Business. Brink. https://www.brinknews.com/the-space-industry-is-getting-down-tobusiness/ 
Civil Convention Against Corruption (2003) An International Document. Dated November 04. http:// zakon3.rada.gov.ua/laws/show/994_102.

Corruption Perceptions Index-2018 (2019) Transparency International. https://ti-ukraine.org/ research/indeks-spryjnyattya-koruptsiyi-2018/

Criminal Convention for the Suppression of Corruption (1999) International Document of January 27. http://zakon2.rada.gov.ua/laws/show/994_101

Guidelines for the effective implementation of the Code of Conduct for Law Enforcement Officials 1989/61 (1961) “Kodeks" http://docs.cntd.ru/document/901744941

International Code of Conduct for Government Officials (1996) International Document of 23.07. https://law.work.gov.ua/laws/show/995_788

Khvorostyankina, Anna (2020) Definitsiyi v zakonodavchykh tekstakh: pytannya teoriyi. Ministerstvo Yustytsiyi Ukrayiny. http://old.minjust.gov.ua/6669

Klimova, Svetlana, and Tatiana Kovalova (2015) Orhanizatsiyno-pravove zabezpechennya suchasnoyi antykoruptsiynoyi polityky. Kharkivs'kyy rehional'nyy instytut derzhavnoho upravlinnya Natsional'noyi akademiyi derzhavnoho upravlinnya pry Prezydentovi Ukrayiny.

Kobzar, Oleksandr, and Anna Danylenko (2019) International and National Provisions of Space Law Regulating the Use of Outer Space. Advanced Space Law, Volume 3: 48-62. https://doi.org/10.29202/asl/2019/3/4

Malysheva, Nataliia, and Anna Hurova (2019) Legal forms of public-private partnership for the space activity of Ukraine and its distinction from related forms of contractual cooperation. Space Science and Technology, 25(1): 73-84. https://doi.org/10.15407/ knit2019.01.073

Measures against corruption practiced by transnational and other corporations, their intermediaries, and other parties involved (1975) UN General Assembly Resolution of 15 December 1975, № 3514 (XXX). https://undocs.org/ru/A/RES/3514\%28XXX\%29

Model Law "Fundamentals of Anti-Corruption Policy Legislation" (2003) International document dated 15.11.2003. https://zakon.rada.gov.ua/laws/show/997_944/ ed $20031115 /$ find?text $=\%$ CF $\%$ F0\%E5\%E4\%F3\%EF\%F0\%E5\%E6\%E4\%E5\%ED $\%$ E $8 \% \mathrm{E} 5+\% \mathrm{EA} \% \mathrm{EE} \% \mathrm{~F} 0 \% \mathrm{~F} 0 \% \mathrm{~F} 3 \% \mathrm{EF} \% \mathrm{~F} 6 \% \mathrm{E} 8 \% \mathrm{E} 8$

Petrashko, Sergiy (2011) Konventsiya OON proty koruptsiyi: universalizatsiya standartiv u sferi protydiyi koruptsiyi. Naukovyy visnyk Uzhhorods'koho universytetu : seriya: Pravo; v 2-kh chastynakh. Lira. Vyp. 15 №CH. 2. S. 90-94.

Pro derzhavno-pryvatne partnerstvo (2010). Zakon Ukrainy vid 01.07. № 2404-VI, Vidomosti Verkhovnoi Rady Ukrainy, 2010, № 40, st.524 zi zminamy vid 10.06.2018. URL: http:// zakon.rada.gov.ua/laws/show/2404-17

Resolution (98) 7 authorizing the partial and enlarged Agreement establishing the "Group of States against Corruption - GRECO” (1998). (adopted by the Committee of Ministers on 5 May 1998, at its 102nd Session). https://www.coe.int/en/web/greco/key-documents

Resolution (97) 24 (1997) Twenty Principles for the Fight against Corruption of the Committee of Ministers of the Council of Europe: International Document No. R (97) 24.11.1997. https://rm.coe.int/16806cc17c

The future of the European space sector: How to leverage Europe's technological leadership and boost investments for space ventures (2019) European Investment Bank. https:// www.eib.org/attachments/thematic/future_of_european_space_sector_en.pdf 
Tkalya, O., and Pravova, V. (2011) Definitsiya: ponyattya, znachennya ta rol' v zakonodavchiy praktytsi. Lyudyna i zakon : publichno-pravovyy vymir: materialy Mizhnar. nauk.-prakt. konf. «VII Prybuz'ki yurydychni chytannya»; za red. S. V. Kivalova, V. O. Tulyakova, O. V. Kozachenka. Ilion. pp. 65-67.

To Infinity and Beyond - Global Space (2017) Bank of America Merrill Lynch. https://api. guidants.com/db/a2/1e1ffc185c1d44bd.pdf

Trepak, Victor (2015) Osoblyvosti definitsiyi ponyattya «koruptsiya». Naukovyy visnyk Natsional'noyi akademiyi vnutrishnikh sprav. № 4. S. 181-196.

United Nations Convention against Corruption (2003) International document of 31 October. http://zakon3.rada.gov.ua/laws/show/995_c16.

United Nations Convention against Corruption (2004) https:/www.unodc.org/documents/ treaties/UNCAC/Publications/Convention/08-50026_E.pdf

Vanovskaya, Oksana (2018) Psykholohyya korruptsyonnoho povedenyya hosudarstvennykh sluzhashchykh 2-e uzd/ Yzdatel'stvo Yurayt.

Zadorozhniy, Oleg (2016) Mizhnarodno-pravovi standarty borot'by z koruptsiyeyu. Realizatsiya derzhavnoyi antykoruptsiynoyi polityky $\mathrm{v}$ mizhnarodnomu vymiri: materialy Mizhnarod. nauk.-prakt. konf. (Kyiv, 09/12/ 2016 r.). Kyiv: Nats. akad. vnutr. Sprav, pp. 49-55.

Zinchuk, Alexander (2018) Konventsiya OON proty koruptsiyi: pravovyy bazys zapobihannya ta protydiyi koruptsiyi v Ukrayini. http://www.minjust.gov.ua/0/21048 